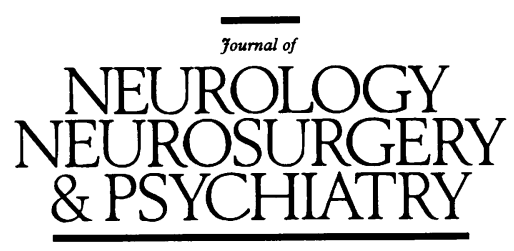

Editorial

\title{
Coagulation abnormalities and cerebral infarction
}

Thrombosis is central to the major pathophysiological mechanisms of ischaemic stroke-large vessel occlusive disease, embolism and small vessel occlusion. Whilst in the majority of cases the thrombotic process becomes activated secondarily to an underlying (cardio)vascular pathology, some cases of ischaemic strokes may result primarily from an abnormality of the haemostatic mechanisms which results in unchecked thrombus formation within the cerebral circulation.

There is a requirement, in health, for the rapid and efficient sealing of breaches in the vascular endothelium, whilst at the same time uncontrolled vessel occlusion cannot be permitted. This has led to the evolution of an interactive system of cellular and fluid-phase components, activators and inhibitors designed to fulfil these requirements. The participants are blood platelets, components of the fluid phase of coagulation and their inhibitors, the fibrinolytic system and the vascular endothelium.

Platelets are highly reactive, contractile and secretory anucleate cells which have the capacity to interact with components of the vascular subendothelium within seconds of their exposure. The response requires the availability of adhesive proteins and specific platelet membrane glycoprotein receptors. von Willebrand factor (vWF), a macromolecule synthesised by vascular endothelial cells and megakaryocytes, is the principal protein involved. Subsequently platelets may interact in a process of aggregation, to form an occlusive plug. In this process fibrinogen and other adhesive proteins act as intercellular bridges by interaction with platelet membrane glycoproteins. Inappropriate platelet activation is limited by the local secretion by vascular tissues of short-lived potent inhibitors of platelet adhesion and aggregation. The most important are prostaglandin $I_{2}$ and nitric oxide, which exert their inhibitory action through the stimulation of cyclic nucleotide synthesis within platelets.

\section{Blood coagulation (figure)}

A series of zymogens and cofactors interact in the generation of insoluble fibrin from its soluble precursor protein fibrinogen, through the action of thrombin. Thrombin plays a central role in haemostasis as it is also one of the more potent platelet agonists and in addition acts as a trigger for the activation of a major natural anticoagulant system (the protein $\mathrm{C} / \mathrm{S} /$ thrombomodulin system).

The final pathway of thrombin generation from pro- thrombin involves the formation of an activator complex of factors $\mathrm{X}$ and $\mathrm{V}$, with calcium, on a phospholipid surface, provided in vivo by activated platelets. This "final common pathway" brings together the intrinsic system of coagulation activation by surface contact and the extrinsic system which becomes activated by release of tissue factor (thromboplastin). The result of coagulation and platelet activation is the haemostatic plug formed of a platelet aggregate stabilised by fibrin.

\section{Coagulation inhibitors}

Knowledge is increasing of physiological inhibitory mechanisms which oppose uncontrolled fibrin formation. Three important inhibitors of coagulation have been well defined-antithrombin (formerly antithrombin III), protein $\mathrm{C}$ and its cofactor protein S. Antithrombin is the major serine protease inhibitor, with particular activity against activated factor $\mathrm{X}(\mathrm{Xa})$ and thrombin, but also against factors XIIa, XIa and $\mathrm{XXa}$ in the extrinsic pathway. This inhibitory capacity is increased considerably by heparin-like molecules (glycosaminoglycans) present in vascular tissues in vivo, as well as by heparin given therapeutically.

Activated protein $C$ inhibits the activated form of coagulation factors VIII and V (VIIIa and Va). For the full expression of protein $\mathrm{C}$ activation a cofactor, protein $S$, is necessary. Thrombin, and an endothelium-derived cofactor, thrombomodulin, are necessary for protein $\mathrm{C}$ activation.

\section{Fibrinolysis}

The fibrinolytic mechanism provides a further check on unopposed thrombus formation. Plasmin, cleaved from the zymogen plasminogen by tissue plasminogen activator (t-PA) or urokinase, is able to digest fibrin to soluble fibrin-degradation products. In common with the coagulation system, interplay between activators and inhibitors modulates the fibrinolytic process.

\section{The vascular endothelium}

The vascular lining is a complex secretory organ which exerts major controlling effects on haemostasis and blood flow. All aspects of haemostasis are influenced by endothelium, for example by secretion of prostacyclin, nitric oxide, vWF and t-PA. Protein C activation occurs on the endothelial surface and heparin-like molecules, responsible for massive augmentation of the inhibitory effects of antithrombin, are components of the vessel wall. 


\section{Disturbances of haemostatic mechanisms and thrombosis}

In a broad sense there is an undoubted relationship between arterial occlusive disease, including stroke, and coagulation mechanisms. Fibrinogen and factor VII concentrations are at least as potent as cholesterol as risk factors for arterial occlusion. ${ }^{12}$ Platelet count and volume have also been implicated as risk factors. ${ }^{3}$ Haemostatic mechanisms are probably involved in the development and progression of atheroma as well as being central to the formation of the platelet/fibrin thrombus which occurs during the acute occlusive event. The role of ulcerated atheroma, with presumed platelet activation on exposed subendothelial material, in the genesis of transient cerebral ischaemic attack (TIA) and stroke is clear. ${ }^{4}$ The efficacy of aspirin, an inhibitor of platelet aggregation, in the reduction of ischaemic episodes and lowering of the incidence of completed stroke ${ }^{5}$ further supports the role of platelets in cerebrovascular occlusion.

The concept of a prethrombotic state has been developed, and such a condition clearly occurs in certain situations. The mechanisms, however, are as yet unclear and may be multifactorial. Thrombosis in pregnancy and that associated with oral contraceptive use and the prethrombotic state which undoubtedly accompanies malignant disease are examples.

More specifically, certain well-defined haemostatic disorders are undoubtedly associated with an increased thrombotic risk. These disorders are the "congenital thrombophilias", due to deficiency of a natural anticoagulant (protein $\mathrm{C}$, protein $\mathrm{S}$ or antithrombin), the acquired disorder known as the primary antiphospholipid syndrome, where the presence of an auto-antibody to phospholipids is associated with increased thrombotic

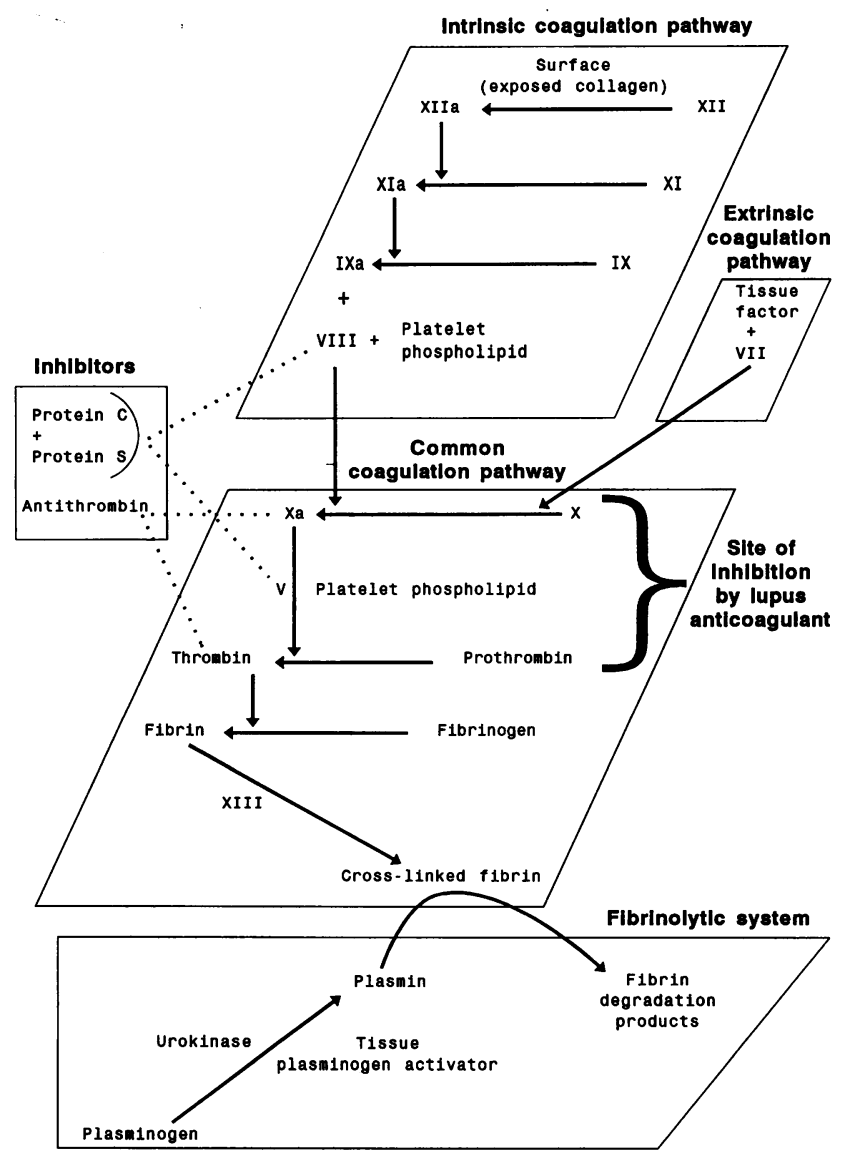

Figure $A$ scheme of the coagulation and fibrinolytic mechanisms risk, and the myeloproliferative diseases essential thrombocythaemia and polycythaemia rubra vera, where thrombocytosis with or without increased platelet reactivity contributes to a thrombotic tendency. This review will concentrate on these conditions, although microvascular occlusion, often with neurological involvement, is a major feature also of some other disorders in which haemostatic mechanisms are disturbed, including disseminated intravascular coagulation, thrombotic thrombocytopenic purpura and the haemolytic uraemic syndrome. ${ }^{6}$

\section{Specific coagulation disorders and stroke Antibodies to phospholipid}

Considerable interest has been generated in recent years in the relationship between antiphospholipid, detected in plasma as lupus anticoagulant or in serum as anticardiolipin, and a tendency to thrombosis, both venous and arterial. A coagulation inhibitor was first described in SLE in $1952^{7}$ and the term "lupus anticoagulant" has persisted, despite the paradoxical association with thrombosis $^{8}$ rather than haemorrhage and the knowledge that these antibodies to phospholipid are common in subjects without the features of SLE.

Lupus anticoagulant is thus a member of a heterogenous group of antibodies with varying specificities apparently for negatively charged phospholipid. Others are anticardiolipin and the antibodies responsible for the biological false positive VDRL. Lupus anticoagulant, by its activity against the phospholipid necessary for coagulation activation, especially in the common pathway, is detected by prolongation of the clotting time in phospholipid-dependent tests of coagulation (figure). Anticardiolipin is measured by solid-phase immunoassay with cardiolipin as the phospholipid antigen. It is now considered that lupus anticoagulant and anticardiolipin represent separate antibodies within a family of autoantibodies directed against protein phospholipid complexes rather than phospholipid itself. Recent data suggest these probably include a complex between an anticoagulant glycoprotein- $\beta_{2}$ glycoprotein $1\left(\beta_{2}\right.$ GP1) or Apo $\mathrm{H}$-and negatively charged phospholipids, ${ }^{9}$ and that between prothrombin and phospholipid. ${ }^{10}$

\section{The occurrence of antiphospholipid}

Antiphospholipid may be detected in up to around $50 \%$ of subjects with SLE and less commonly in other autoimmune diseases, including rheumatoid arthritis, temporal arteritis and immune thrombocytopaenia. ${ }^{11}$ Transiently positive tests, especially for anticardiolipin, may occur after acute infective episodes and also in chronic infections, including syphilis, malaria and some viral infections. Tissue injury may be the trigger for the development of anticardiolipin after acute myocardial infarction and in subjects with coronary artery bypass grafts. ${ }^{12}$ Exposure of "neoantigens", during tissue repair may underlie the development of antiphospholipid. Other associations are Behçet's syndrome and skin disorders, especially livedo reticularis. ${ }^{11}$ Apparently drug-induced antiphospilipid occurs during medication with phenothiazines, especially chlorpromazine, hydrallazine, phenytoin and some other compounds. Crucially, antiphospholipid may be found in subjects who have no predisposing or associated condition and these subjects may be at risk of thrombosis.

\section{Thrombosis and antiphospholipid}

Although causality has not been demonstrated, positive tests for antiphospholipid have been associated with 
thrombotic disease. Thus in SLE, the risk of thrombotic complications is increased some $2-5$ fold in subjects with lupus anticoagulant. ${ }^{13}$ Thrombosis may occur in the venous, arterial or microvascular systems. Deep venous thrombosis is most commonly seen, but stroke, sometimes in young subjects without other recognised risk factors, undoubtedly occurs. ${ }^{1415}$ Brey et al ${ }^{16}$ reported detectable antiphospholipid in 21 of $46(46 \%)$ subjects under 50 years of age presenting with stroke or TIA, compared with only 2 of $26(8 \%)$ in matched controls with non-thrombotic neurological disease. Retrospective studies tend to confirm a tendency to presentation at a young age, the frequent absence of the clinical and laboratory evidence of collagen vascular disease, and a predisposition to recurrent and multiple events. ${ }^{17-19}$ In a large retrospective study, stroke recurrence occurred at a rate of $9.4 \%$ over 16 months following the presenting cerebrovascular event. ${ }^{20}$ The same group found an adjusted odds ratio of 2.4 for the presence of anticardiolipin in 248 unselected subjects presenting with stroke compared with hospitalised controls, suggesting that the presence of anticardiolipin is an independent risk factor for stroke.

Strokes are usually ischaemic and most commonly arterial events, although cerebral venous thrombosis has been described. In one study cerebral angiography was normal in over one third ( $37 \%$ of 49 cases) of subjects. ${ }^{20}$ This, together with the finding of branch occlusions without corresponding carotid artery lesions in many other subjects, led the authors to postulate in situ intravascular thrombosis or cardiac embolism as the cause. ${ }^{20}$ Angiographic evidence of vasculitis is uncommon.

Visual disturbance and chorea ${ }^{21}$ may be particular associations in subjects with antiphospholipid. Central retinal artery and retinal branch occlusion, ${ }^{22-24}$ retinal vein thrombosis, ischaemic optic neuropathy ${ }^{25}$ and amaurosis fugax ${ }^{2627}$ are reported. In Sneddon's syndrome ${ }^{28}$ cerebrovascular disease occurs in association with livedo reticularis. This purple mottling of the skin is probably a manifestation of dermal venous thrombosis and antiphospholipid have been detected in a high proportion of subjects with the syndrome, suggesting an involvement in the prethrombotic state.

Cardiac valvular lesions, especially of the mitral valve, are more common in SLE patients who also have antiphospholipid. ${ }^{29}$ The abnormalities range from valve prolapse to thickened cusps and vegetations. In subjects with antiphospholipid but no evidence of collagen vascular disease valve abnormalities have also been reported $^{30-33}$ and this could clearly be relevant to the pathogenesis of stroke in such individuals.

An increased incidence of neurological conditions other than stroke, in subjects with positive tests for antiphospholipid, has also been postulated. These include migraine, Guillain-Barré syndrome, myelopathies and the neurological complications of Behçet's syndrome. ${ }^{34}$ The precise relationship between antiphospholipid and these conditions remains speculative.

A further association is of clinical and diagnostic importance. It is apparent that in young women with antiphospholipid, either within or without the spectrum of SLE, a pronounced tendency to pregnancy complications is manifest. ${ }^{35} 36$ Recurrent (three or more) miscarriage, ${ }^{37}$ intrauterine growth retardation, early severe pre-eclampsia and chorea gravidarium are described. Placental infarction has been noted and these associations may therefore sometimes have a thrombotic basis.

\section{The primary antiphospholipid syndrome}

This term has been used to describe the syndrome of positive tests for antiphospholipid in a subject without SLE but with one or more of the strongly associated clinical states: recurrent miscarriage, thrombosis, or thrombocytopaenia.

\section{Pathogenic mechanisms for thrombosis}

Negatively-charged phospholipid is an essential cofactor in fibrin generation, hence the effect of antiphospholipid on in vitro tests of coagulation. Similar phospholipids, however, are exposed on platelet activation and, importantly, are also necessary for activation of the major anticoagulant mechanism involving proteins $\mathrm{C}$ and $\mathrm{S}$ and thrombomodulin; there is evidence for interference in the function of activated protein $\mathrm{C}$, by antiphospholipid, and these antibodies could also augment platelet aggregability. ${ }^{30-40}$ Other studies suggest a disturbance of vascular endothelial function in the presence of antiphospholipid, with reduced prostacyclin synthesis and enhanced release of the platelet adhesive cofactor von Willebrand factor. ${ }^{41}$ Interference with fibrinolytic mechanisms has also been noted, ${ }^{42}$ although not reproducibly. Vascular endothelial cell antibodies appear to be present in many antiphospholipid-containing sera. ${ }^{43}$ These could well be of pathogenic importance in thrombotic manifestations, suggesting that antiphospholipid may serve only as surrogate markers for other relevant cytotoxic auto-antibodies.

\section{Testing for antiphospholipid}

The heterogeneous nature of antiphospholipid raises important considerations relating to the laboratory route to diagnosis. ${ }^{44} \mathrm{~A}$ comprehensive approach is necessary which must include a coagulation screening test, a confirmatory coagulation-based assay and a solid-phase assay such as the well characterised and standardised enzymelinked immunosorbent assay for IgG and IgM antibody to cardiolipin. The kaolin cephalin clotting time (KCCT) is available in almost all coagulation laboratories and is a useful screening test for lupus anticoagulant, although sensitivity is highly reagent dependent. The dilute Russell's viper venom time (DRVVT) with a confirmatory phospholipid neutralisation step to demonstrate specificity, or the kaolin clotting time (KCT), performed with dilutions of normal plasma, are useful additional tests. These coagulation assays are sensitive to lupus anticoagulant but do not provide firm quantitative information. Recommendations for their performance and interpretation have been published. ${ }^{45}$

It is important that some lupus anticoagulant will be detected in one appropriate assay and the alternative test may be negative and also that positivity in the anticardiolipin assay is not necessarily accompanied by abnormal coagulation test results. Clinical experience suggests that those samples testing positive for lupus anticoagulant \pm anticardiolipin are more commonly associated with thrombosis than those positive for anticardiolipin only and that IgG anticardiolipin are of greater pathogenic significance than IgM anticardiolipin, but these distinctions are far from absolute. Also, low titre anticardiolipin are a common finding of doubtful significance and transiently positive tests for anticardiolipin, such as those occurring in infections, may also be of less clinical importance. Such antibodies are most frequently of IgM isotype. Demonstration of persistence and, in anticardiolipin assays, isotype and titre are therefore essential in the interpretation of test results.

\section{Hereditary thrombophilia}

Of the many theoretical abnormalities of the haemostatic control mechanisms which could predispose to thrombo- 
sis, only three have proved clinically important to date; these are deficiencies of antithrombin, protein $C$ and protein $S$. The clinical significance of other inherited conditions, such as heparin cofactor II deficiency, hypoplasminogenaemia and other defects of the fibrinolytic system, is either minor or unproven.

The association between familial deficiency of antithrombin and thromboembolism was recognised in 1965. ${ }^{46}$ Deficiency is inherited in autosomal dominant fashion with a prevalence estimated between 1 in 2000 and 1 in 40000 in different series. Such deficiency accounts for $2-5 \%$ of episodes of venous thromboembolism in adults presenting below the age of 45 years. ${ }^{47}$ Thrombotic events are rare in childhood, but the risk of thrombosis in an affected individual is estimated to be $65 \%$ between the ages of 15 and 30 years. ${ }^{47}$ In $80-90 \%$ of cases there is a parallel reduction in antithrombin antigen and its functional activity, typically to a level of $50-70 \%$ of mean normal-Type I deficiency. In Type II or variant deficiency there is a point mutation in the portion of the molecule responsible for heparin or thrombin binding, with reduced functional activity but normal levels of antigen.

Proteins $\mathrm{C}$ and $\mathrm{S}$ are vitamin $\mathrm{K}$ dependent proteins. Familial deficiencies were first described in $1981^{48}$ and $1984^{49}$ respectively. The prevalence of protein C deficiency is unclear, as although up to 1 in 200 healthy asymptomatic blood donors have low levels, ${ }^{50}$ symptomatic deficiency is much less common-perhaps being as low as 1 in $36000 . .^{51}$ It thus appears that the heterozygous state can be clinically silent. It does, however, account for around 5\% of episodes of venous thromboembolism in young adults and individuals in clinically affected kindreds appear to have an $80 \%$ chance of a thrombotic event by the age of 40 years. Type I and Type II defects are again recognised, in protein C deficiency. The homozygous state is most commonly associated with life-threatening thrombosis in the neonatal period, although exceptions have been noted, with survival to adult life..$^{52}$

Protein $\mathrm{S}$ exists in plasma in free form, in which it can act as a cofactor for activated protein C, but also complexed in an inactive state with the acute phase protein $\mathrm{C} 4 \mathrm{~b}-$ binding protein $(\mathrm{C} 4 \mathrm{bBP})$. In the more common Type I heterozygous deficiency, levels of free protein $S$ are very low, almost all being bound to C4bBP. Type II deficiency, characterised by low levels of both free and bound protein, is rare. The thrombosis risk is similar to that in protein $\mathrm{C}$ deficiency. ${ }^{53}$

\section{Stroke and inherited thrombophilia}

Unsurprisingly, sagittal sinus and cortical venous thrombosis have been reported in all three deficiency states ${ }^{54-63}$ and this is consistent with the high incidence of venous thromboembolism, which often occurs in unusual sites.

There are numerous reports of cerebral infarction due to arterial thrombosis in subjects with apparent deficiency of antithrombin, ${ }^{64-70}$ protein $C^{71-80}$ or protein S. $59647481-85$ However, the relationship between stroke and inherited thrombophilia is apparently far weaker than that with antiphospholipid, and is undoubtedly extremely small compared with the risk of a venous thromboembolic event.

Protein S deficiency in subjects with angiographic evidence of intracerebral arterial occlusion has been reported. ${ }^{628285}$ However, only rarely has familial thrombophilia been conclusively diagnosed, by demonstration of persistence of the deficiency remote from the acute event, and by detection of clinically affected family members. ${ }^{62}$ This is of particular relevance in protein $S$ deficiency, as increases in C4bBP as part of the acute phase response may result in an acquired reduction in free (functional) protein $S$ which is not necessarily causal in the thrombotic event. Sie et $a^{83}$ studied 23 subjects in 17 families with protein S deficiency. Six had a history of arterial thrombosis, in three cases involving the cerebral vessels. In contrast, in a survey of 136 subjects from 12 kindreds no case of symptomatic arterial occlusive disease was found, ${ }^{53}$ and in another series no case of deficiency of total protein $S$ among 50 young survivors of stroke was detected. ${ }^{79}$ However, Sacco et al, ${ }^{59}$ found reduced plasma protein $S$ in 21 of 103 stroke patients, but no follow up or family study was performed.

A similar picture has emerged in relation to protein $\mathrm{C}$ deficiency and stroke. In a study of 50 consecutive subjects suffering stroke at an age of 45 years or less, ${ }^{79}$ three had Type. I familial protein $\mathrm{C}$ deficiency. In contrast, although cerebral venous thrombosis was recorded in three subjects, no case of arterial thrombosis was found in 53 protein $C$ deficient individuals from 20 welldocumented families with inherited deficiency. ${ }^{72}$ Stroke in Type II deficiency has also been reported, ${ }^{80}$ as has stroke in a child with the acquired protein $\mathrm{C}$ deficiency which may occur after high-dose chemotherapy. ${ }^{78}$ Again it is important to note that transient (acquired) protein $C$ deficiency may be detected in the acute phase of stroke, and indeed this may be a marker of poor outcome. $^{75}$

Stroke in familial antithrombin deficiency has rarely been reported. Consumption of antithrombin during thrombosis results in a transient fall in the plasma level and such an abnormality was noted in three subjects in a survey of 45 consecutive episodes of stroke. ${ }^{67}$ Interestingly, there are two reports of stroke in young subjects with variant antithrombin with reduced heparin binding. ${ }^{65} 68$

To settle the controversy on whether familial thrombophilia predisposes to cerebral arterial occlusive disease, more information is required on the prevalence of these deficiencies in the healthy population, as well as in those with stroke and non-vascular neurological disease. Although some well conducted surveys have suggested a high prevalence of deficiency of protein $C$ and $S$ when young stroke patients are screened, this has not been a consistent finding. At present it seems reasonable to conclude that deficiency of a natural anticoagulant, congenital or acquired, may add to the risk of arterial thrombosis, in the presence of other risk factors.

\section{Thrombocytosis and stroke}

Neurological manifestations are frequently noted in essential thrombocythaemia, which is a clonal marrow disorder, one of the myeloproliferative diseases, in which the predominantly affected cell type is the megakaryocyte. Peripheral blood platelet counts in excess of 1000 $\times 10^{9} / 1$ are not uncommon, but extensive thrombotic disease can be associated with counts around $600 \times 10^{9} / 1$ in this disease. A total of $85 \%$ of affected individuals are over 50 years of age, although stroke in younger subjects may be a presenting event.

Neurological manifestations have included transient ischaemic episodes, visual disturbance, uncinate and focal epilepsy, and cerebellar ataxia, as well as hemiplegia. ${ }^{86-89}$ Slowly progressive stroke may occur..$^{90}$ Thrombosis of dural sinuses and otherwise typical benign intracranial hypertension are other complications of this disorder. ${ }^{91-94}$

Similar events may occur in another myeloproliferative disorder, polycythaemia rubra vera. ${ }^{95-98}$ Here, tissue hypoxia is often due to hyperviscosity secondary to a 
raised haematocrit, but megakaryocytic proliferation, with thrombocytosis, may contribute. ${ }^{99}$

In contrast, stroke is uncommon in non-myeloproliferative thrombocytosis. Raised blood platelet count is a reactive phenomenon in chronic inflammatory or neoplastic disease, as well as after tissue trauma, in the presence of chronic bleeding and after splenectomy. Intracranial vascular events have only occasionally been reported in this setting. ${ }^{99-103}$

\section{Screening for coagulation abnormalities in thrombotic stroke}

An automated full blood count will reliably detect the presence of essential thrombocythaemia in subjects presenting with stroke, although repeat testing and further investigation will be necessary to exclude a reactive thrombocytosis. An elevated red cell count and haemotocrit, often with a thrombocytosis, will alert to the possibility of polycythaemia rubra vera, confirmation being by exclusion of causes of secondary polycythaemia and demonstration of a raised body red cell mass.

More difficult is the decision to screen for antiphospholipid and for familial thrombophilia. Screening for the presence of antiphospholipid using the range of laboratory tests described above is justified in subjects presenting at an age of 50 years or less with thrombotic stroke, especially where other risk factors are absent. When stroke occurs against a background of recurrent thrombosis, thrombocytopaenia, manifestations of collagen vascular disease or recurrent miscarriage, screening for antiphospholipid is particularly likely to be fruitful. The possible significance of positive tests should be confirmed by demonstration of reproducibility over a period of at least three months.

Assay of antithrombin, protein $\mathrm{C}$ and protein $\mathrm{S}$, which is relatively expensive, is not justified at present in the routine investigation of cerebral arterial thrombosis, although the availability of further epidemiological data may allow the identification of subgroups where screening is likely to be productive. Performance of these assays may be justified in subjects with apparently spontaneous cerebral cortical venous thrombosis or in stroke where there is also a strong family history of venous thromboembolism.

Other tests of coagulation, such as platelet aggregation assays, fibrinogen concentration, coagulation factor assays and tests of fibrinolysis are not indicated, as the clinical significance, if any, of the often transient abnormalities which may occur is open to doubt.

\section{Therapeutic considerations}

In stroke due to essential thrombocythaemia, it is logical to recommend cytoreductive therapy, and usually also aspirin, as prophylaxis against further thrombotic events. Hydroxyurea has been increasingly favoured over alkylating agents and radiophosphorus, as the risk of transformation to a leukaemic state with long-term therapy appears to be lower. The role of $\alpha$-interferon in this disorder remains controversial.

In subjects with antiphospholipid several therapeutic strategies have been adopted. Antiplatelet agents, anticoagulants, corticosteroids and other immunosuppressive drugs have been used. In the absence of non-thrombotic autoimmune manifestations, immunomodulatory therapy is not appropriate, at least as the initial therapeutic strategy, unless anticoagulant treatment has failed. Corticosteroids, immunosuppressant drugs, plasma exchange and high dose intravenous immunoglobulin have all been the subjects of anecdotal reports, not invariably with successful outcome.

In view of the high rate of recurrent stroke, aspirin or warfarin prophylaxis should be considered. Again, there is a lack of controlled trials to guide management. There are reports of successful use of aspirin or warfarin in individual subjects with cerebrovascular complications but recurrent events have occurred despite treatment. ${ }^{104-108}$ In the cases reported by the APASS ${ }^{108}$ group 13 of 18 subjects treated with antiplatelet agents had further events. Prospective studies are needed as a guide to the appropriate management of stroke in subjects with antiphospholipid. Until then most affected individuals will be given aspirin or warfarin in an attempt to influence the high risk of further stroke.

The diagnosis of inherited thrombophilia is not necessarily an indication for warfarin therapy in the absence of symptoms, but should lead to counselling and the use of prophylaxis during times of high risk, such as pregnancy and the post-partum period and peri-operatively. Longterm warfarin prophylaxis should, however, be considered after a life-threatening thromboembolic event, when the risks of such intervention must be weighed against the perceived risk of recurrence in an individual.

Department of Haematology, M GREAVES

Royal Hallamshire Hospital

Glossop Road,

Sheffield S10 $2 F F, U K$

1 Dalaker K, Hjermann I, Prydz H. A novel form of factor VII in plasma from men at risk for cardiovascular disease. Brit $f$ Haematol 1985;61:315-22.

2 Meade TW, Mellows S, Brozovic M, et al. Haemostatic function and ischaemic heart disease: principal results of the Northwick Park Heart Study. Lancet 1986;2:533-7.

3 D'Erasmo E, Aliberti G, Celi FS, Romagnoli E, Vecci E, Mazzuoli GF. Platelet count, mean platelet volume and their relation to prognosis in cerebral infarction. F Intern Med 1990;227:11-4.

4 Amarenco P, Duyckaerts C, Tzourio C, Henin D, Bousser M-G, Hauw J$\mathrm{J}$. The prevalence of ulcerated plaques in the aortic arch in patients with stroke. New Eng $\mathcal{F}$ Med 1992;326:221-5.

5 The SALT Collaborative Group. Swedish Aspirin Low-Dose Trial (SALT) of $75 \mathrm{mg}$ aspirin as secondary prophylaxis after cerebrovascular ischaemic events. Lancet 1991;338:1345-9.

6 Greaves M, Davies Jones G A B. Systemic diseases, Pt1. In: Goetz CG, Tanner CM, Aminoff MJ, eds. Handbook of clinical neurology, Vol 19(63). Amsterdam: Elsevier, 1992.

7 Conley CL, Hartmann RC. A haemorrhagic disorder caused by circulating anticoagulant in patients with disseminated lupus erythematosus. $f$ Clin Invest 1952;31:621-3.

8 Bowie WEJ, Thompson JH, Pascuzzi CA, Owen GA. Thrombosis in systemic lupus erythematosus despite circulating anticoagulant. $f$ Clin Invest 1963;62:416-30.

9 McNeil HP, Simpson RJ, Chesterman CN, Krilis SA. Antiphospholipid antibodies are directed against a complex antigen that includes a lipidbinding inhibitor of coagulation: $\beta$-glycoprotein I (apolipoprotein $\mathrm{H}$ ). Proc Natl Acad Sci USA 1990;87:4120-4.

10 Bevers EM, Galli M, Barbui T, Comfurius P, Zwaal RFA. Lupus anticoagulant IgG's (LA) are not directed to phospholipids only, but to a complex of lipid-bound human prothrombin. Thrombos Haemostas complex of lipid-

11 Greaves M, Preston FE. Clinical and laboratory aspects of thrombophilia. In: Poller L, ed. Recent advances in blood coagulation. London: Churchill Livingstone 1991:119-40

12 Hamsten A, Norberg R, Bjorkholm M, de Faire U, Holm G. Antibodies to cardiolipin in young survivors of myocardial infarction: an association with recurrent cardiovascular events. Lancet 1986;1:113-6.

13 Petri M, Hochberg M, Hellman D, Corash L, Goldman D. The association of the lupus anticoagulant (LA) with thrombotic events (TE) in systemic lupus erythematosus (SLE). Clin Exp Rheumatol 1990;8:217.

14 Kushner MJ. Prospective study of anticardiolipin antibodies in stroke. Stroke 1990;21:295-8.

15 Levine SR, Deegan MJ, Futrell N, Welch KMA. Cerebrovascular and neurologic disease associated with antiphospholipid antibodies: 48 cases. Neurology 1990;40:1181-9.

16 Brey RL, Hart RG, Sherman TG, Tegeler CH. Antiphospholipid antibodies and cerebral ischaemia in young people. Neurology 1990;40: 1190-6.

17 Kushner M, Simonian N. Lupus anticoagulants, anticardiolipin antibodies, and cerebral ischaemia. Stroke 1989;20:225-9.

18 Levine SR, Brey RL, Joseph CLM, Haustad S. Risk of recurrent thromboembolic events in patients with focal cerebral ischaemia and antiphospholipid antibodies. Stroke 1992;23(Suppl I):I29-I32.

19 Coull BM, Bourdette DN, Goodnight SH, Briley DP, Hart R. Multiple cerebral infarctions and dementia associated with anticardiolipin antibodies. Stroke 1987;18:1107-12.

20 Antiphospholipid Antibodies in Stroke Study Group: Clinical and laboratory findings in patients with antiphospholipid antibodies and cerebral ischaemia. Stroke 1990;21:1268-73. 
21 Asherson RA, Derksen RHWM, Harris EM, Bouma BN, Gharavi AE, Kater L, Hughes GRV. Chorea in systemic lupus erythematosus and "lupus-like" disease: Association with antiphospholipid antibodies. Sem "lupus-like" disease: Associa

22 Asherson RA, Baguley E, Khamashta MA, Hughes GRV. Multiple smallvessel occlusions in systemic lupus erythematosus. Stroke 1989;20: $127-8$.

23 Levine SR, Crofts JW, Lesser GR, Floberg J, Welch KMA. Visual symptoms associated with the presence of a lupus anticoagulant. Ophthalmology 1988;95:686-92.

24 Kleiner RC, Najarian LV, Schatten S, Jabs DA, Patz A, Kaplan HJ. Vaso-occlusive retinopathy associated with antiphospholipid antibodies (lupus anticoagulant retinopathy). Ophthalmology 1989;96: 896-904.

25 Watts MT, Greaves M, Clearkin LG, Malia RG, Cooper SM. Antiphospholipid antibodies and ischaemic optic neuropathy. Lancet 1990;335:613-4.

26 Briley DP, Coull BM, Goodnight SH. Neurological disease associated with antiphospholipid antibodies. Ann Neurol 1989;25:221-7.

27 Digre KB, Durcan FJ, Branch DW, Jacobson DM, Varner MW, Baringer JR. Amaurosis fugax associated with antiphospholipid antibodies. Ann Neurol 1989;25:228-32.

28 Sneddon IB. Cerebro-vascular lesions and livedo reticularis. Brit $\mathcal{f}$ Dermatol 1965;77:180-1.

29 Ford PM, Forde SE, Lillicrap DP. Association of lupus anticoagulant with severe valvular heart disease in systemic lupus erythematosus. $\mathcal{F}$ Rheumatol 1988;15:597-60.

30 Ford SE, Lillicrap D, Brunet D, Ford P. Thrombotic endocarditis and lupus anticoagulant. Arch Pathol Lab Med 1989;113:350-3.

31 D'Alton JG, Preston DN, Bormanis J, Green MS, Kraag GR. Multiple transient ischaemic attacks, lupus anticoagulant and verrucous endocarditis. Stroke 1985;16:512-4.

32 Anderson D, Bell D, Lodge G, Grant E. Recurrent cerebral ischaemia and mitral valve vegetation in a patient with antiphospholipid antibodies. F Rheumatol 1987;14:839-41.

33 Young SM, Fisher M, Sigsbee A, Errichetti A. Cardiogenic brain embolism and lupus anticoagulant. Ann Neurol 1989;26:390-2.

34 Levine SR, Welch KMA. The spectrum of neurologic disease associated with antiphospholipid antibodies. Arch Neurol 1987;44:876-83.

35 Branch DW, Scott JR, Lochenour NK, Hershgold E. Obstetric complications associated

36 Lockshin MD, Druzin ML, Goei S, Qamar T, Magid MS, Jovanovic L, Ferenc M. Antibody to cardiolipin as a predictor of fetal distress or death in pregnant patients with systemic lupus erythematosus. New Engl death in pregnant patient

37 Creagh MD, Duncan SLB, McDonnell J, Greaves $M$. The incidence of the lupus anticoagulant (LA) and anticardiolipin antibodies (ACL) in normal pregnancy. Clin Exp Rheumatol 1990;8:219.

38 Cariou R, Tobelin G, Belluci S, Soria J, Soria C, Maclouf J, Caen J. Effect of the lupus anticoagulant on antithrombogenic properties of endothelial cells - inhibition of thrombomodulin dependent protein $\mathrm{C}$ activation. Thrombos Haemostas 1988;60:54-8.

39 Marciniak E, Romond EH. Impaired catalytic function of activated protein C: a new in vitro manifestation of lupus anticoagulant. Blood 1989;74:2426-32.

40 Malia RG, Kitchen S, Greaves M, Preston FE. Inhibition of activated protein $\mathrm{C}$ and its cofactor protein $\mathrm{S}$ by antiphospholipid antibodies. Brit protein C and its cofactor pro

41 Lindsey NJ, Henderson F, Malia RG, Greaves M, Hughes P. Serum masks the inhibition of thrombin-induced prostacyclin release produced
by anticardiolipin antibodies. Brit $\mathcal{F}$ Rheumatol $1992 ; 31: 179-83$.

42 Angeles-Cano E, Sultan Y, Clauvel JP. Predisposing factors to thrombosis in systemic lupus erythematosus: possible relation to endothelial cell damage. $\mathcal{F}$ Lab Clin Med 1979;94:312-23.

43 Lindsey NJ, Henderson FI, Dawson R, Malia R, Greaves M, Hughes P. The effect of immunoglobulin $G$ from patients with systemic lupus erythematosus (SLE) and the antiphospholipid syndrome (APS) on the release of von Willebrand factor antigen (vWF) from human umbilical vein endothelium. Brit 7 Rheumatol 1991;2:(Abst Suppl): 19.

44 Creagh MD, Greaves M. Lupus Anticoagulant. Blood Reviews 1991;5:162-7.

45 Machin SJ, Giddings J, Greaves M, Hutton R, Mackie IJ, Malia RG, Taberner DA. Detection of the lupus like anticoagulant: current laboraTaberner DA. Detection of the lupus like anticoagulant: current lab

46 Egeberg $O$. Inherited antithrombin III deficiency causing thrombophilia. Thrombos Diath Haemorrhagica 1965;13:516-30.

47 Hirsh J, Piovella S, Pini M. Congenital antithrombin III deficiency. Am $\mathcal{F}$ Med 1989;87:(Suppl 3B)34-8

48 Griffin JH, Evatt B, Zimmerman TS, Kleiss AJ, Widenman C. Deficiency of protein $\mathrm{C}$ in congenital thrombotic disease. $\mathcal{f}$ Clin Invest 1981;68:1370-3.

49 Comp PC, Nixon RR, Cooper MR, Esmon CT. Familial protein S deficiency associated with recurrent thrombosis. $f^{\text {Clin }}$ Invest 1984;74:2082-99.

50 Miletich J, Sherman L, Broze G. Absence of thrombosis and subjects with heterozygous protein C deficiency. New Engl F Med 1987;317:991-6.

51 Gladson CL, Sharrer I, Hach V, Beck KH, Griffin JH. The frequency of type I heterozygous protein C deficiency in 141 unrelated young

52 Tripodi A, Franchi F, Krachmalnicoff A, Mannucci PM. Asymptomatic homozygous protein C deficiency. Acta Haematol (Basel) 1990;83: homozy.

53 Engesser L, Broekmans AW, Briet E, Brommer EJP, Bertina RN. Hereditary protein $\mathrm{S}$ deficiency; clinical manifestations. Ann Intern Med Hereditary protein

54 Ambruso DR, Jacobson LJ, Hathaway WE. Inherited antithrombin III deficiency and cerebral thrombosis in a child. Pediatrics 1980;65: 125-31.

55 Lee $\mathrm{M}-\dot{\mathrm{K}}$, Ng S-C. Cerebral venous thrombosis associated with antithrombin III deficiency. Aust NZ $\mathfrak{F}$ Med 1991;21:772-3.

56 Demers C, Ginsberg JS, Hirsh J, Henderson P, Blajchman MA. Thrombosis in antithrombin III-deficient persons. Ann Int Med 1992; 116:754-61.
57 Barbui T, Finazzi G, Mussoni L, Riganti M, Donati MB, Colucci M Collen D. Hereditary dysfunctional protein C (protein C Bergamo) and hrombosis. Lancet 1984;2:819.

58 Vieregge P, Schwieder G, Kompf O. Cerebral venous thrombosis in hereditary protein C deficiency. F Neurol Neurosurg Psychiatry 1989; 52:135-7.

59 Sacco RL, Owen J, Mohr JP, Tatemichi TK, Grossman BA. Free protein $S$ deficiency: A possible association with cerebrovascular occlusion. Stroke 1989;20:1657-61

60 Pasquale LR, Moster ML, Schmaier A. Dural sinus thrombosis with abnormalities of protein S and fibrinogen. Arch Ophthalmol 1990 108:644.

61 Cros D, Comp PC, Beltran G, Gum G. Superior sagittal sinus thrombosis in a patient with protein $S$ deficiency. Stroke 1990;21:633-6.

62 Green D, Otoya J, Oriba H, Rovner R. Protein S deficiency in middleaged women with stroke. Neurology 1992;42:1029-33.

63 Koelman JHTM, Bakker CM, Plandsoen WCG, Peeters FLM, Barth PG. Hereditary protein $S$ deficiency presenting with cerebral sinus thrombosis in an adolescent girl. $\mathcal{F}$ Neurol 1992;239:105-6.

64 Sakuragawa N, Takahashi K, Shin-ichi K, Koide T. Antithrombin III Toyama: A hereditary abnormal antithrombin III of a patient with recurrent thrombophlebitis. Thromb Res 1983;31:305-17.

65 Fischer AM, Cornu P, Sternberg C, et al. Antithrombin III Alger: A new homozygous AT III variant. Thrombos Haemostas 1986;55:218-21.

66 Ueyama H, Hashimoto Y, Uchino M, Sasaki Y, Uyama E, Okajima K, Araki S. Progressing ischaemic stroke in a homozygote with varian antithrombin III. Stroke 1989;20:815-8.

67 Ernerudh J, Olsson JE, von Schench H. Antithrombin III deficiency in ischaemic stroke. Stroke 1990;21:967.

68 Donnet A, Khalil R, Terrier G, Koeppel M-C, Niee BT, Aillaud M-F Cerebral infarction, livedo reticularis, and familial deficiency in antithrombin III. Stroke 1992;23:611-2.

69 Shinmyozu K, Ohkatsu Y, Maruyama Y, Osame M, Igata A. A case of congenital antithrombin III deficiency complicated by an internal carotid artery occlusion. Clin Neurol 1986;26:162-5.

70 Vomberg PP, Breedenveld C, Fleury P, Arts WFM. Cerebral thromboembolism due to antithrombin III deficiency in two children. Neuropaediatrics 1987;18:42-4.

71 Smith DB, Ens GE. Protein C deficiency: a cause of amaurosis fugax? $\mathcal{f}$ Neurol Neurosurg Psychiatry 1986;50:361-2.

72 Wintzen AR, Broekmans AW, Bertina RM, et al. Cerebral haemorrhagic infarction in young patients with hereditary protein C deficiency: Evidence for "spontaneous" cerebral venous thrombosis. BMF 1985; 290:350-2.

73 Velasco F, Andres P, Canadillas F, Fornes G, Torres A. Transient ischaemic attack (TIA) in a patient with non-thrombogenic hereditary
protein $C$ deficiency under oral contraceptives. Thrombos Haemostas protein C defic

74 Israels SJ, Seshia SS. Childhood stroke associated with protein C or S deficiency. $\mathcal{F}$ Pediatr 1987;111:562-4.

75 D'Angelo A, Vigano-D'Angelo S, Esmon CT, Comp PC. Acquired deficiencies of protein S. $\mathcal{F}$ Clin Invest 1988;81:1145-54.

76 Dusser A, Boyer-Neumann C, Wolf M. Temporary protein C deficiency associated with cerebral arterial thrombosis in childhood. $\mathcal{f}$ Pediat 1988;113:849-51.

77 Kohler J, Kasper J, Witt I, von Reutern G-M. Ischaemic stroke due to protein C deficiency. Stroke 1990;21:1077-80.

78 Gordon BG, Saving KL, McCallister JA, et al. Cerebral infarction associted with protein $\mathrm{C}$ deficiency following allogeneic bone marrow transplantation. Bone Marrow Tran 1991;8:323-5.

79 Camerlingo M, Finazzi G, Casto L, Laffranchi C, Barbui T, Mamoli A Inherited protein $C$ deficiency and non-haemorrhagic arterial stroke in young adults. Neurology 1991;41:1371-3.

80 Matsushita K, Kuriyama Y, Sawada T, Uchida K Cerebral infarction associated with protein C deficiency. Stroke 1992;23:108-11.

81 Wallis DE, Godwin J. Mitral valve prolapse, cerebral ischaemia, and protein $S$ deficiency. $A m \mathcal{F}$ Med 1988;84:974.

82 Girolami A, Simioni P, Lazzaro AR, Cordiano I. Severe arterial cerebral thrombosis in a patient with protein $S$ deficiency (moderately reduced total and markedly reduced free protein S): a family study. Thrombos Haemostas 1989;61:144-7.

83 Sie P, Boneu B, Bierme R, Wiesel ML, Grunebaum L, Cazenave JP. Arterial thrombosis and protein $\mathrm{S}$ deficiency. Thrombos Haemostas 1989;62:1040.

84 Conard J, Horellou MH, Van Dreden P, Samama M. Thrombosis and reonancy in congenital deficiencies in ATIII protein C or Protein $S$ : pregnancy in congenital deficiencies in ATIII, protein C

85 Davous P, Horellou M, Conard J, Samama M. Cerebral infarction and familial protein S deficiency. Stroke 1990;21:1760-1.

86 Ozer FL, Rauz WE, Miesch DC, Levine WC. Primary haemorrhagic thrombocythaemia. Am $\mathcal{F}$ Med 1960;28:809.

87 Levine J, Swanson PD. Idiopathic thrombocytosis. A treatable cause of transient ischaemic attacks. Neurology 1968;18:711-3.

88 Jabaily J, Iland HJ, Laszlo J, Massdey EWM, Faguet GB, Biere J, Landaw A A Pisciotta AV. Neurologic manifestations of essential thrombocythaemia. Ann Int Med 1983;99:513-8.

89 Delangre T, Mihout B, Borth J-Y, Samson M. Primary thrombocytosis in a patient with cerebellar infarction. Stroke $1985 ; 16: 524-6$.

90 Benassi G, Ricci P, Calbucci F, Cacciotore FM, D'Alessandro R. Slowly progressive ischaemic stroke as first manifestation of essential thromboprogressive ischaemic stroke as first
cythaemia. Stroke 1989;20:1271-2.

91 Mitchell D, Fisher J, Irving D, Gazzard BG, Guiloff RJ. Lateral sinus thrombosis and intracerebral haemorthage in essential thrombothrombosis and intracerebral haemorrhage in essenta

92 Esack A, Thompson G, Burmester $H$. Benign intracranial hypertension and essential thrombocythaemia. $\mathcal{f}$ Neurol Neurosurg Psychiatry 1989;57:914.

93 McDonald TD, Tatemichi TK, Kranzler SJ, Chi C, Hilal SK, Mohr JP Thrombosis of the superior sagittal sinus associated with essential thrombocytosis followed by MRI during anticoagulant treatment Neurology 1989;39:1554-5.

94 Murphy MF. Clarke CRA, Brearley RL. Superior sagittal sinus thrombosis and essential thrombocythaemia. $B M 7$ 1983;287:1344.

95 Millikan CH, Siekert RG, Whisnant JP. Intermittent carotid and verte- 
bral-basilar insufficiency associated with polycythaemia. Neurology 1960;10:188-96.

96 Chievitz E, Thiede T. Complications and causes of death in polycythaemia vera. Acta Med Scand 1962;172:513-23.

97 Pearson TC, Wetherley-Mein G. Vascular occlusive episodes and venous haematocrit in primary proliferative polycythaemia. Lancet 1978:2:1219-22.

98 Najeon Y, Mugnier P, Dresch C, Rain JD. Polycythaemia vera in young people: An analysis of 58 cases diagnosed before 40 years. Brit $\mathcal{f}$ Haem people: An analysi

99 Dawson AA, Ogston D. The influence of the platelet count on the incidence of thrombotic and haemorrhagic complications in polycythaemia vera. Postgrad Med F 1970;46:76-8.

100 Pines A, Kaplinsky N, Olchosky J, Bregman J, Frank O. Recurrent transient ischaemic attacks associated with thrombocytosis in rheumatoid arthritis. Clin Rheumatol 1982;1:291-3.

101 Casado Naranjo I, Gonzalez RM, Rieger JS, Guitart JM, Catala JC. Transient ischaemic attacks associated with thrombocytosis in active rheumatoid arthritis. F Neurol Neurosurg Psychiatry 1988;51:1599.

102 Heller DS, Pervez NK, Kleinerman J. Fatal cerebrovascular thrombosis in a young man: an unusual complication associated with hypochromic anaemia and thrombocytosis following surgery. Mt Sinai $\mathfrak{f} M e d$ 1988;55:318-20.

103 Belman AL. Cerebral venous thrombosis in a child with iron deficiency anaemia and thrombocytosis. Stroke 1990;21:488-93.

104 Landi G, Calloni MV, Sabbadini MG, Mannucci PM, Candelise L. Recurrent ischaemic attacks in two young adults with lupus anticoagulant. Stroke 1983;14:377-9.

105 Levine SR, Kim S, Deegan MJ, Welch KMA. Ischaemic stroke associated with anticardiolipin antibodies. Stroke 1987;18:1101-6.

106 Barbui T, Finazzi G, Falanga A, Cortelazzo S. Intravenous gamma globulin, antiphospholipid antibodies, and thrombocytopenia. Lancet ulin, antip

107 Babikian VL, Call GK, Norrving B, et al. Antiphospholipid antibodies and stroke. Clinical and radiological features, In: Meyer JS, Lechner $\mathrm{H}_{\text {, }}$ Reivich M, eds. Cerebral vascular disease, Vol 7. New York/Amsterdam: Elsevier, 1989; 213-6.

108 Antiphospholipid Antibodies in Stroke Study Group. Recurrent throm boembolic and stroke risk in patients with neurological events and antiphospholipid antibodies. Ann Neurol 1990;28:226.

\section{Neurological stamp}

\section{Karl Friedrich Hieronymus von Munchausen (1720-97)}

Baron Munchausen served in the Russian army in the war against the Turks from 1763-72. After a distinguished military career he retired from the army to manage the family estate near Hanover where he amused and sometimes astounded his friends and relations with recollections of his adventures during the war. The tales were collected together by R E Raspe and first published in England in 1785 in the book Baron Munchausen's narratives of his marvellous travels and campaigns in Russia. These were subsequently published in many languages and new editions appeared with more stories based on contemporary events. The name of Munchausen came to symbolise the preposterous and amusing stories containing grandiose but engaging lies.

In 1951 Richard Asher coined the term "Munchausen syndrome" to describe a syndrome of addiction to hospital in which adults invented false symptoms and signs. Professor Roy Meadows has used the term "Munchausen by Proxy" to describe the fabrication of an illness on behalf of someone else-usually a mother on behalf of her child.

This stamp was issued in 1970 by Germany on the 250th anniversary of the Baron's birth (Stanley Gibbons 1522; Scott 1020). 